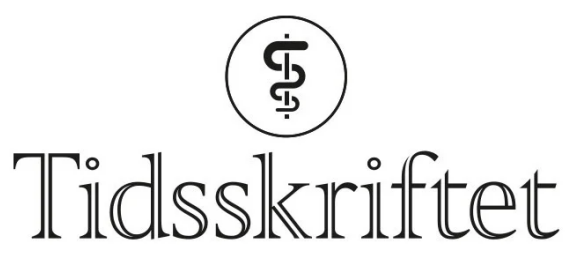

DEN NORSKE LEGEFORENING

\title{
Refleksjon om kurasjon
}

\author{
KOMMENTAR
}

\section{HENRIK JESPERSEN}

henrik.jespersen@ahus.no

Henrik Jespersen er PhD og overlege ved onkologisk avdeling, Akershus universitetssykehus. Forfatteren har ikke oppgitt noen interessekonflikter

Tusen takk til forfatterne av artikkelen «En kvinne i 8o-årene med brystsmerter under immunterapi mot melanom», for at de deler denne lærerike historien på en pedagogisk måte. Det var både spennende og skremmende å lese. Vekten av kunnskapsutveksling og tverrfaglig samarbeid i møtet med pasienter behandlet med immunterapi, illustreres tydelig med de to kanskje mest fryktede av bivirkningene: myokarditt og nevrologiske bivirkninger.

Jeg ønsker bare å oppfordre til refleksjon rundt en av artikkelens innledende setninger: «Per i dag finnes det ikke dokumentasjon på at systemisk behandling ved inoperable lymfeknutemetastaser eller fjernmetastaser fra malignt melanom kan gi kurasjon» (1).

Da blir mitt motspørsmål: Hvilken dokumentasjon kreves for å kunne si at en behandling kan gi kurasjon? Ser vi for på tallene fra den store fase III studien med kombinasjonsimmunterapi ved metastatisk melanom, ser vi, som forfatterne selv påpeker, at over halvparten av pasientene lever i mer enn fem år. Majoriteten av disse har ikke fått noen ytterligere systembehandling etter immunterapien, som for de fleste ble avsluttet flere år tidligere. Hos 20 \% av pasientene er all radiologisk påvisbar sykdom borte, og andelen pasienter uten progresjon av sykdommen ses å plane ut på et konstant nivå (ca. $40 \%$ ) fra to til fem års oppfølgning (므). Om en pasient som har en sykdom som ikke lenger går å påvise, ikke påvirker kroppen, og ikke krever noen form for behandling år etter år, ser på seg selv som kurert, anser jeg det i alle fall ikke som min jobb å hevde noe annet. At pasienten må lære seg å leve med risikoen for tilbakefall er klart, men det gjelder jo i høy grad også for pasienter som har gjennomført det vi tradisjonelt kaller kurativ onkologisk behandling. Michielin og kolleger diskuterer emnet på en nyansert og god måte i en oversiktsartikkel fra i for (3). Med støtte i tilgjengelige langtidsdata fra flere kliniske studier kommer de også med ett forslag på en definisjon på det de kaller funksjonell kurasjon: «We propose that some patients might be considered functionally cured if they have responded to treatment and remained treatment-free for at least 2 years without disease progression» (3).

Uansett definisjoner og semantikk, er det i alle fall sikkert at de langvarige behandlingseffektene vi iblant ser med immunterapi har bidratt til å viske ut den tidligere så skarpe dikotomien mellom palliativ og kurativ behandling. Utsiktene for en langvarig 
behandlingsrespons gjør det også motivert å akseptere mer alvorlige bivirkninger enn for en tradisjonell palliativ kreftbehandling. Dette krever at kunnskap om immunrelaterte bivirkninger spres på tvers av fagområder, hvilket artikkelforfatterne har bidratt med på en utmerket måte.

\section{LITTERATUR}

1. Karlsen TLS, Karlsen J, Mo R et al. En kvinne i 8o-årene med brystsmerter under immunterapi mot melanom. Tidsskr Nor Legeforen 2021; 141. doi: 10.4045/tidsskr.20.0982. [CrossRef]

2. Larkin J, Chiarion-Sileni V, Gonzalez R et al. Five-Year Survival with Combined Nivolumab and Ipilimumab in Advanced Melanoma. N Engl J Med 2019;381: 1535-46. [PubMed][CrossRef]

3. Michielin $\mathrm{O}$, Atkins MB, Koon $\mathrm{HB}$ et al. Evolving impact of long-term survival results on metastatic melanoma treatment. J Immunother Cancer 2020; 8: eooog48. [PubMed][CrossRef]

Publisert: 27. september 2021. Tidsskr Nor Legeforen. DOI:10.4045/tidsskr.21.0626

(C) Tidsskrift for Den norske legeforening 2023. Lastet ned fra tidsskriftet.no 26. april 2023. 